\title{
Multidimensional Separations of Ubiquitin Conformers in the Gas Phase: Relating Ion Cross Sections to H/D Exchange Measurements
}

\author{
Errol W. Robinson and Evan R. Williams \\ Department of Chemistry, University of California at Berkeley, Berkeley, California, USA
}

Investigating gas-phase structures of protein ions can lead to an improved understanding of intramolecular forces that play an important role in protein folding. Both hydrogen/deuterium $(\mathrm{H} / \mathrm{D})$ exchange and ion mobility spectrometry provide insight into the structures and stabilities of different gas-phase conformers, but how best to relate the results from these two methods has been hotly debated. Here, high-field asymmetric waveform ion mobility spectrometry (FAIMS) is combined with Fourier-transform ion cyclotron resonance mass spectrometry (FT/ICR MS) and is used to directly relate ubiquitin ion cross sections and H/D exchange extents. Multiple conformers can be identified using both methods. For the $9+$ charge state of ubiquitin, two conformers (or unresolved populations of conformers) that have cross sections differing by $10 \%$ are resolved by FAIMS, but only one conformer is apparent using H/D exchange at short times. For the 12+ charge state, two conformers (or conformer populations) have cross sections differing by $<1 \%$, yet $\mathrm{H} / \mathrm{D}$ exchange of these conformers differ significantly (6 versus 25 exchanges). These and other results show that ubiquitin ion collisional cross sections and H/D exchange distributions are not strongly correlated and that factors other than surface accessibility appear to play a significant role in determining rates and extents of H/D exchange. Conformers that are not resolved by one method could be resolved by the other, indicating that these two methods are highly complementary and that more conformations can be resolved with this combination of methods than by either method alone. (J Am Soc Mass Spectrom 2005, 16, 1427-1437) (C) 2005 American Society for Mass Spectrometry

$\mathrm{U}$ nderstanding biomolecule conformation and folding is an important challenge in chemistry $[1,2]$. In solution, many experimental methods for determining biomolecular conformation have been developed, including NMR, crystallography, and mass spectrometry based methods. Effects of solvent on molecular structure and folding are often inferred indirectly from experiments done with different solvent systems. In the gas phase, molecular conformation can be investigated using gas-phase H/D exchange [3-6], ion mobility spectrometry (IMS) [7-9], proton transfer reactivity $[10,10 \mathrm{~b}, 10 \mathrm{~d}]$, ion-surface imprinting [11], molecular dynamics simulations [12], ion energy loss measurement [13, 14], and dissociation experiments [15]. These experiments provide insight into the conformations of ions in the complete absence of solvent, and from such experiments, the effects of solvent on molecular structure can be directly determined.

Pioneering gas-phase H/D exchange experiments of McLafferty and coworkers clearly demonstrated that multiple conformations of proteins can exist in the gas

Published online July 14, 2005

Address reprint requests to Dr. E. R. Williams, Department of Chemistry, University of California at Berkeley, Berkeley, CA 94720, USA. E-mail: williams@cchem.berkeley.edu phase [3]. For cytochrome $c$, a total of seven different gas-phase conformers were identified based on different extents of $\mathrm{H} / \mathrm{D}$ exchange. Interestingly, several charge states formed directly by electrospray ionization had only one conformer whereas others were found to have multiple conformers with the $7+$ charge state having all seven. In combination with charge stripping as well as IR heating with a $\mathrm{CO}_{2}$ laser, gas-phase proteins were found to both unfold as well as fold in the complete absence of solvent [3b]. Subsequent proton transfer reactivity and IMS experiments have also demonstrated gas-phase protein folding [2, 9d, 10a]. Implicit in the interpretation of the H/D exchange data is the assumption of a relationship between the extents of $\mathrm{H} / \mathrm{D}$ exchange and surface accessibility, and its relation to the compactness of a conformer. However, some evidence has suggested surface accessibility may not be a dominant factor in H/D exchange extents for some peptides and proteins $[2,5,16]$.

From ion mobility spectroscopy, it is possible to obtain collisional cross sections of gas-phase ions from which information about structure can be inferred. This method has been used extensively for obtaining detailed information on small ions and atomic clusters [17]. For proteins, multiple distinct gas-phase conformers have been observed [2, 7-9]. In general, cross 
sections increase with ion charge state. For example, cytochrome $c$ charge states below $5+$ have cross sections that are slightly lower than the cross section calculated for a native solution structure. The cross section of the 19+ approaches the calculated cross section for a fully extended conformer [9a]. For intermediate charge states, as many as five different conformers have been identified. Interestingly, the cross sections of the more open conformers increase with charge state whereas McLafferty and coworkers [3b] found that H/D exchange extents for the four most open conformers decrease with charge state. This result is consistent with increased local structure around charge sites for these conformers [3b]. Jarrold has shown that more compact protein conformers hydrate more readily and that gas-phase hydration can result in the folding of more open conformers [2].

A key difficulty in comparing results from $H / D$ exchange to IMS results is that these two methods probe different physical properties of an ion. In addition, H/D exchange experiments and the ion mobility spectroscopy experiments typically measure ion conformation on two very different time frames. Ion mobility experiments probe ion conformation within $\sim 10 \mathrm{~ms}$ of their formation, whereas $\mathrm{H} / \mathrm{D}$ exchange experiments done in Fourier-transform ion cyclotron resonance (FT/ICR) mass spectrometers typically probe ion conformation several seconds or even hours after ion formation. Clemmer and coworkers investigated the effects of storing ions for up to $30 \mathrm{~s}$ in an RF ion trap before their analysis by IMS [9a, b]. They observed that some compact conformer populations unfolded during this time frame whereas others did not. Valentine and Clemmer have also investigated H/D exchange in the drift tube of an ion mobility spectrometer [18]. They did not observe a charge state dependence to $\mathrm{H} / \mathrm{D}$ exchange extents for a given conformer separated by IMS, but they did report that compact structures underwent less exchange than more open structures.

High-field asymmetric waveform ion mobility spectrometry (FAIMS), a method based on principles first demonstrated by Buryakov et al. [19], has recently been applied to the separation of protein conformers [14, 20, 20a]. The separation is based on the dependence of ion mobility on the electric field strength. In FAIMS, ions pass between two cylindrical electrode surfaces across which an asymmetric RF potential waveform is applied, alternately exposing the ions to strong and weak electric fields. Different mobilities of the ions during the high field versus low field portion of the waveform result in the ions drifting towards one of the electrodes. This drift can be compensated for by using a DC potential. By varying this "compensation" voltage $(\mathrm{CV})$, ions are separately transmitted through the FAIMS device into the mass spectrometer. This method has the advantage over the more widely used drift tube ion mobility spectroscopy experiments in that very high ion transmission is possible [21], and the method can be readily used with virtually any type of mass spectrometer. A current limitation is that it is not readily possible to obtain absolute cross sections from these experiments.

Purves et al. have used FAIMS to separate different conformers of bovine ubiquitin [14]. In combination with ion retarding potential measurements, it was possible to obtain ion cross sectional measurements as a function of $\mathrm{CV}$ values. The cross sections obtained using this method were larger than those reported by Clemmer and coworkers [9c, 10c] for these same ions. However, by normalizing their data to the $13+$ charge state for which there was only one conformer identified using both techniques, Purves et al. [14] reported that the remaining cross sections closely matched the ion mobility data, with an average deviation of $1.5 \%$. A few additional conformers were resolved using FAIMS [14].

Here, we report the combination of FAIMS with $\mathrm{H} / \mathrm{D}$ exchange experiments done in FT/ICR MS to investigate the structure of ubiquitin ions. Ubiquitin ions were chosen because they have been investigated by energy loss measurements in combination with FAIMS, IMS, and H/D exchange. These experiments for the first time make possible a direct comparison between H/D exchange experiments in FT/ICR MS with collisional cross section measurements by IMS. We find that $\mathrm{H} / \mathrm{D}$ exchange extents do not significantly correlate to collisional cross sections and that these methods for conformer separation appear to be highly complementary, with many conformers identified by one method, but not the other.

\section{Experimental}

\section{FT/ICR Mass Spectrometer}

The Berkeley-Bruker 9.4 tesla FT/ICR mass spectrometer is used for all experiments [22]. Tons are produced by electrospray ionization using a $0.1 \mathrm{~mm}$ i.d. stainless steel capillary connected to a syringe pump system to maintain a solution flow rate of $2 \mu \mathrm{L} / \mathrm{min}$. This capillary was positioned $5 \mathrm{~mm}$ away from the ion entrance hole in the FAIMS device and a voltage of $2000 \mathrm{~V}$ was applied to the capillary. No nebulizing gas was used. Solutions were prepared from a $1 \times 10^{-3} \mathrm{M}$ stock solution of ubiquitin in water which was stored at $-50{ }^{\circ} \mathrm{C}$ when not in use. A solution of $49.5 / 49.5 / 1 \%$ water/methanol/acetic acid with a bovine ubiquitin concentration of $10^{-5} \mathrm{M}$ was used for electrospray ionization. The $\mathrm{D}_{2} \mathrm{O}$ and bovine ubiquitin used in these experiments were obtained from Sigma-Aldrich Co. (St. Louis, MO) and were used as received. Methanol and acetic acid were obtained from Fisher Scientific (Fair Lawn, NJ) and were used as received.

$\mathrm{H} / \mathrm{D}$ exchange was performed by introducing $\mathrm{D}_{2} \mathrm{O}$ into the mass spectrometer through a piezoelectric valve attached to the ultrahigh vacuum chamber. This valve is controlled using the Xmass data acquisition software (Bruker Daltonics, Billerica, MA). This valve is opened for 10 to $60 \mathrm{~s}$ during which time the pressure is $\sim 8 \times 10^{-7}$ torr as measured on an uncalibrated ion 
gauge located $\sim 1.5 \mathrm{~m}$ from the ion cell. After the valve is closed, a $120 \mathrm{~s}$ delay before ion detection is used to allow the system to pump down and reach a pressure of $\sim 2 \times 10^{-8}$ torr. The number of deuteriums incorporated is calculated from the mass difference between the center of the exchanged isotope distribution and the center of the isotope distribution with no H/D exchange. The extent of H/D exchange at a given exchange time was reproducible to under \pm 3 deuteriums incorporated. This variation in $\mathrm{H} / \mathrm{D}$ exchange extents correlated to pressure changes in the $\mathrm{D}_{2} \mathrm{O}$ reservoir. After the experiments reported here, modifications to the gas inlet system improved H/D exchange reproducibility. No difference was detected between H/D exchange experiments with and without isolation of neighboring charge states. Therefore, no isolation in the ion cell was used in these experiments.

An extended pseudo-open cylindrical cell was built and used in these experiments. Improved resolution and ion storage during $H / D$ exchange was obtained using this cell compared with the cell used previously [22]..$^{\circ}$ The ${ }^{\circ}$ total ${ }^{\circ}$ length ${ }^{\circ}$ of ${ }^{\circ}$ the ${ }^{\circ}$ cell $^{\circ}$ is ${ }^{\circ} 300^{\circ} \mathrm{mm}^{\circ}$ with ${ }^{\circ}$ an ${ }^{\circ}$ i.d. of $60 \mathrm{~mm}$. This cell is similar to other open cylindrical cell $^{\circ}$ designs ${ }^{\circ}[23]^{\circ} \operatorname{except}^{\circ}$ that ${ }^{\circ}$ the ${ }^{\circ}$ excite $/$ detect $^{\circ}$ plates $^{\circ}$ of the cell have been extended to $150 \mathrm{~mm}$ long relative to the $60 \mathrm{~mm}$ trapping cylinders. Thus, the length of the excite/detect plates is 2.5 times the length of the trapping cylinders. Capacitive coupling between the excite/ detect ${ }^{\circ}$ plates ${ }^{\circ}$ and $^{\circ}{ }^{\circ}$ lindrical ${ }^{\text {trapping }}$ plates $[24]$ has not yet been incorporated in this cell. The open cylindrical design was further modified by the inclusion of several additional trapping plates. These vertical plates allow ions to be trapped with similar experimental conditions as the previous cell. During ion injection, the potential on the trapping plates is $4 \mathrm{~V}$. Nitrogen gas is pulsed into the mass spectrometer to assist in trapping the ions. The voltage on the trapping plates is then raised linearly to $6 \mathrm{~V}$ in $1.5 \mathrm{~s}$ for improved ion trapping during H/D exchange. The voltage on the trapping plates is then linearly lowered to $1 \mathrm{~V}$ in $1.5 \mathrm{~s}$ before excitation and detection.

\section{FAIMS}

The Ionalytics Selectra (Ionalytics, Ottawa, Canada) was used for all FAIMS experiments. The FAIMS device is interfaced with the mass spectrometer by using a PEEK sleeve to hold the FAIMS device in proper alignment with ${ }^{\circ}$ the ${ }^{\circ}$ mass $^{\circ}$ spectrometer. $^{\circ}$ An $^{\circ}$ o-ring ${ }^{\circ}$ between $^{\circ}$ the capillary entrance aperture of the mass spectrometer and the exit orifice in the FAIMS device makes possible a gas-tight interface between the two devices. A dispersion voltage (DV) of $-3600 \mathrm{~V}$ and a nitrogen carrier gas flow rate of $2.5 \mathrm{~L} / \mathrm{min}$ produced $\mathrm{CV}$ scans similar to those ${ }^{\circ}$ reported ${ }^{\circ}$ in $^{\circ}$ reference ${ }^{\circ}[14] .{ }^{\circ}$ Optimal ${ }^{\circ}$ performance of the FAIMS device is achieved at dispersion voltage DV values above $-4400 \mathrm{~V}$. However, these higher DV values significantly shift the $C V$ required for ion transmission compared with the $\mathrm{CV}$ scans reported by
Purves $^{\circ}$ et $^{\circ}$ al. $.^{\circ}[14] .^{\circ}$ The $^{\circ}$ experimental $^{\circ}$ conditions $^{\circ}$ of $^{\circ}$ our FAIMS device were chosen to yield $\mathrm{CV}$ scan peaks similar to those obtained by Purves et al. when measuring ubiquitin ${ }^{\circ} \mathrm{Cross}^{\circ}$ sections $^{\circ}[14]$. The $^{\circ} \mathrm{CV}$ is ${ }^{\circ}$ generated by using a spare power supply on the mass spectrometer and this voltage is controlled by the Bruker Xmass software. The acquisition of CV scans was facilitated by the use of a custom Xmass Tcl/Tk script. This script steps a user-selected Xmass variable by a specified increment and range, and saves a mass spectrum at each step. All Bruker Xmass mass spectra data files were processed using $\mathrm{R}$ statistical analysis software ( $\mathrm{R}$ Foundation for Statistical Computing, Vienna, Austria) [25].

\section{Results and Discussion}

\section{$H / D$ Exchange}

To combine H/D exchange with FAIMS over a wide CV range, it is desirable to keep the $H / D$ exchange times as short as possible to reduce the potentially lengthy time required for these experiments. To determine the extent to which different conformers can be resolved using short exchange times, H/D exchange was performed on the entire charge state distribution of ubiquitin using reaction times of 20 and $40 \mathrm{~s}$. The results of these experiments $^{\circ}$ are $^{\circ}$ summarized $^{\circ}$ in $^{\circ}$ Table $^{\circ} 1 .^{\circ}$ For $^{\circ}$ the $^{\circ} 8+$ through $10+$ charge states, the extents of exchange increase roughly linearly with reaction time, and two conformers (or conformer populations) are clearly resolved. For the $7+$ charge state, two very low abundance conformers are resolved at $20 \mathrm{~s}$, but the signalto-noise ratio $(\mathrm{S} / \mathrm{N})$ is insufficient to observe these conformers at $40 \mathrm{~s}$. For the $11+$ and $12+$ charge states, the extent of H/D exchange does not increase linearly with reaction time. Three $11+$ conformers and two $12+$ conformers are clearly resolved. The average difference in exchange is roughly constant at these two exchange times, although a third population appears at $40 \mathrm{~s}$ for the $11+$ that is not apparent at $20 \mathrm{~s}$. For the $13+$ charge state, only one conformer is observed at the shorter reaction time, and no signal is observed at $40 \mathrm{~s}$ because of poor $\mathrm{S} / \mathrm{N}$ for this ion. These results are in striking contrast to recent results of Geller and Lifshitz who resolved two different conformers for only the $13+$ charge state using $\mathrm{ND}_{3}$ as an exchange reagent [6a].

Also $^{\circ}$ included $^{\circ}$ in $^{\circ}$ Table $^{\circ} 1^{\circ}$ are $^{\circ}$ the $^{\circ}$ data $^{\circ}$ obtained $^{\circ}$ by Marshall ${ }^{\circ}$ and ${ }^{\circ}$ coworkers $^{\circ}[4]^{\circ}$ who $^{\circ}$ did $^{\circ} \mathrm{H} / \mathrm{D}^{\circ}$ exchange $^{\circ}$ on ubiquitin ions using $\mathrm{D}_{2} \mathrm{O}$ and $1 \mathrm{~h}$ reaction times. Overall, we find excellent agreement between the results of our H/D exchange done at relatively short times and those of Marshall who used 90- to 180-fold longer reaction times. Of the 144 exchangeable hydrogens in bovine ubiquitin, 6 to 48 deuteriums for the various charge states are incorporated with $40 \mathrm{~s}$ of H/D exchange versus the 27 to 88 hydrogens exchanged as reported by Marshall and coworkers. The number of conformers resolved in both experiments is the same for 


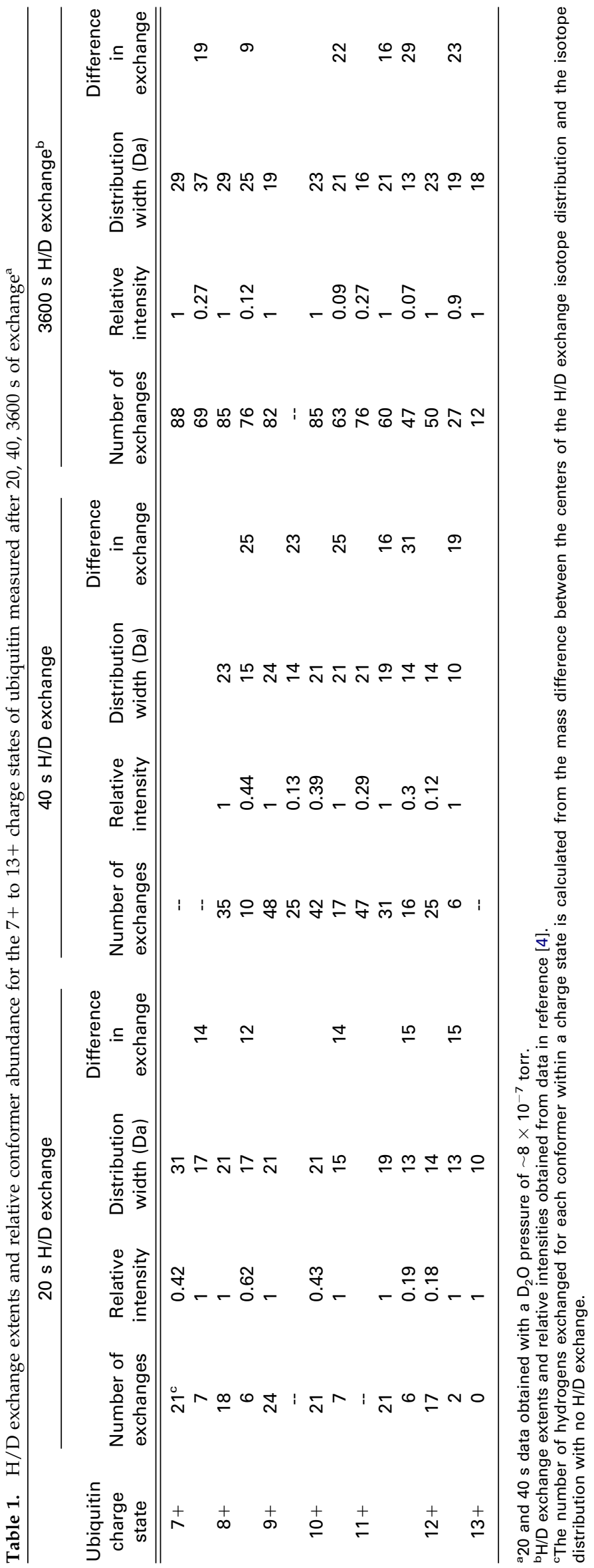




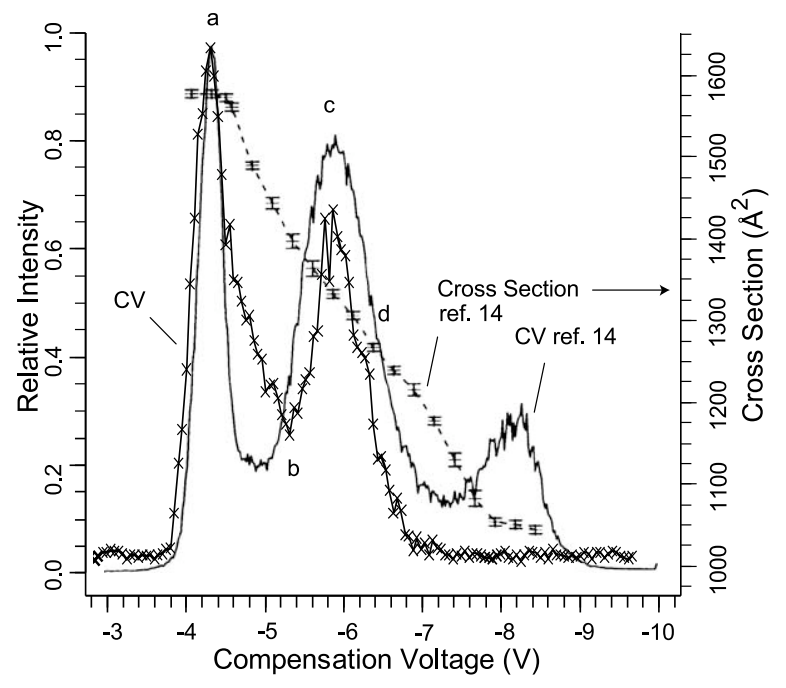

Figure 1. Comparison of a CV scan for the $8+$ charge state of ubiquitin obtained with a FT/ICR mass spectrometer (line with letters $\mathrm{x}$ ) with a scan obtained previously by Purves et al. (solid line) ${ }^{\circ}[14] .{ }^{\circ}$ Collisional ${ }^{\circ}$ cross $^{\circ}$ section ${ }^{\circ}$ measurements ${ }^{\circ}$ made ${ }^{\circ}$ by ${ }^{\circ}$ urves

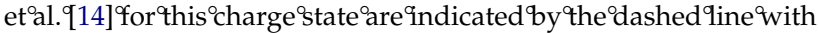
error bars. Letters a to $\mathrm{d}$ indicate $\mathrm{CV}$ values for the $\mathrm{H} / \mathrm{D}$ exchange mass $^{\circ}$ spectra ${ }^{\circ}$ shown $^{\circ}$ in $^{\circ}$ Figure $^{\circ} 3$.

each charge state. The absolute differences in the numbers of exchanges between different conformers of the same charge state are in some cases larger at the significantly shorter reaction times used here. For example, the average difference in $\mathrm{H} / \mathrm{D}$ exchange for the two conformers of the $8+$ charge state is 12,25 , and 9 at 20, 40, and 3600 s. Similarly, a greater difference in absolute exchange is observed for $10+$ charge state at $40 \mathrm{~s}$ than at $3600 \mathrm{~s}$. Thus, higher separation efficiency or conformer resolving power is obtained at short H/D exchange times for the $8+$ through $12+$ charge states for bovine ubiquitin.

The abundances of the isomers observed in these experiments differed from those reported by Marshal and $^{\circ}$ coworkers $^{\circ}[4] .{ }^{\circ}$ For ${ }^{\circ}$ all $^{\circ}$ charge $^{\circ}$ states ${ }^{\circ}$ where ${ }^{\circ}$ multiple conformers are observed (except for the 12+), the relative abundances of the different conformers are more similar in our experiments than those observed by Marshall and coworkers. For the 7+, 10+, and 12+ charge states, the lower exchanging population has the greater abundance at $20 \mathrm{~s}$ and $40 \mathrm{~s}$, but a lower abundance at $3600 \mathrm{~s}$. The different abundances for the various conformers observed in these two experiments are likely due to either different ion source/ion introduction conditions or to isomerization of the conformers during extended H/D exchange times.

The abundances of the isomers can be affected by the length of time ions are accumulated in the hexapole before ion introduction into the FT/ICR cell. Short times $(\sim 0.2 \mathrm{~s})$ resulted in the maximum number of conformers observed. Clemmer and coworkers demonstrated a shift in ion abundances at different cross sections as ion storage time in an ion trap was increased [9a, b], a result consistent with collisional heating that can occur in RF storage devices.

These results indicate that there is no definitive trend in H/D exchange extents with charge states at short reaction times. The maximum extents of exchange are observed for intermediate charge states. In contrast, there appears to be a trend of decreasing $\mathrm{H} / \mathrm{D}$ exchange extent with increasing charge state at the very long exchange time. The H/D exchange results from McLafferty and coworkers noted this trend of decreasing H/D exchange at the higher charge states for several other

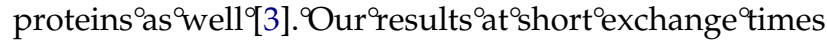
can be attributed to differences in the H/D exchange rates versus the maximum extents of exchange for these different charge states.

\section{Cross Sections}

To relate FAIMS CV values to cross section measurements, it is necessary to essentially "calibrate" FAIMS using another method that can be directly related to the highly accurate cross sections measured using ion mobility spectroscopy. Purves et al. combined FAIMS with energy retarding potential measurements in a triple quadrupole ${ }^{\circ}$ mass $^{\circ}$ spectrometer $^{\circ}[14] .{ }^{\circ}$ Collisional $^{\circ}$ cross sections were determined from measurements of the translational energy that ions lose through collisions with a buffer gas. These cross section values were $\sim 20 \%$ greater than the corresponding cross sections measured by IMS. After normalizing the collisional cross sections measured by translational energy loss to those measured by IMS using the $13+$ charge state as a reference point, the values closely matched, within $1.5 \%$ on average. These measurements make it possible to directly relate $\mathrm{CV}$ values to collisional cross sections for ubiquitin [9c, 14].

Experimental FAIMS conditions were adjusted to obtain CV scans similar to those obtained by Purves et

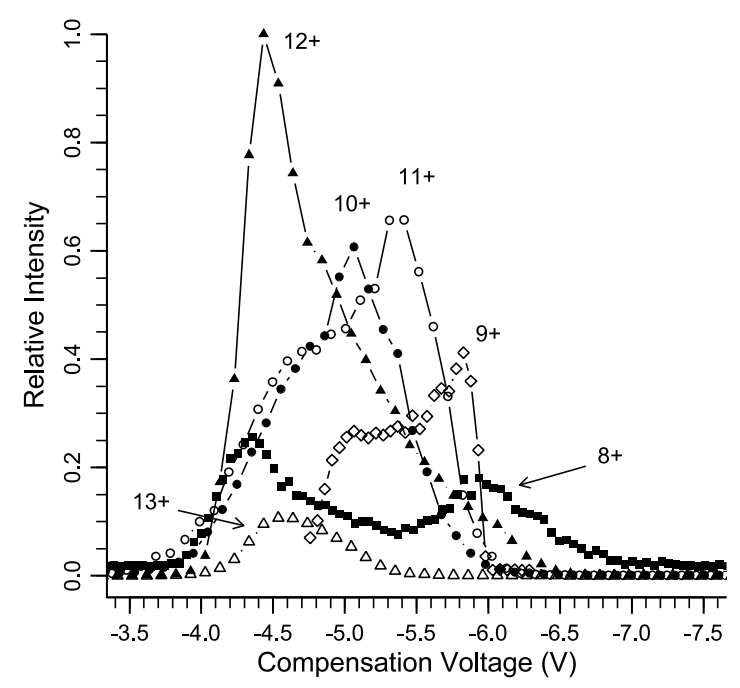

Figure 2. Compensation voltage scans for the $8+$ to $13+$ charge state of bovine ubiquitin. 


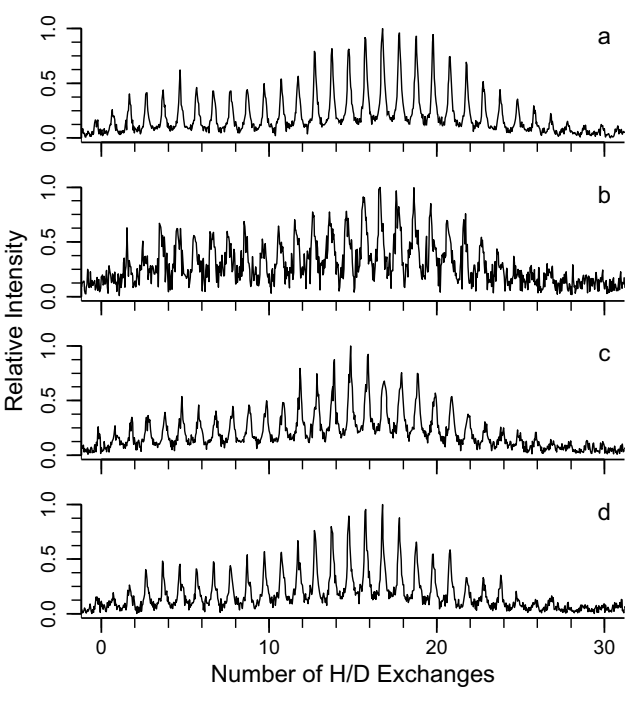

Figure 3. $\mathrm{H} / \mathrm{D}$ exchange mass spectra for the $8+$ charge state of ubiquitin with $20 \mathrm{~s}$ reaction time at $\sim 8 \times 10^{-7}$ torr at compensation voltages of (a) $-4.4 \mathrm{~V},(\mathbf{b})-5.3 \mathrm{~V},(\mathbf{c})-5.9 \mathrm{~V}$, and (d) $-6.5 \mathrm{~V}$ corresponding to a $300 \AA^{2}$ range of collisional cross sections.

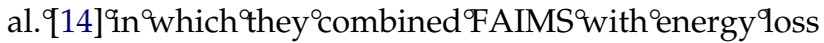
collisional cross section measurements. Results of a CV scan for the $8+$ charge state of ubiquitin under these conditions $^{\circ}$ are $^{\circ}$ shown $^{\circ}{ }^{\circ}{ }^{\circ}$ Figure $^{\circ} 1 .^{\circ}$ Also $^{\circ}$ shown $^{\circ}$ on $^{\circ}$ this same plot is the CV scan for this same ion measured by Purves $^{\circ}$ et $^{\circ}$ al. $^{\circ}[14]^{\circ}{ }^{\circ}$ as $^{\circ}$ we $^{\circ} l^{\circ}$ as $^{\circ}$ their ${ }^{\circ}$ collisional ${ }^{\circ}$ cross section values measured as a function of $\mathrm{CV}$. Our FAIMS CV scans indicate the presence of two clearly resolved conformers, or two families of unresolved conformers compared with three observed by Purves et al., a result that is likely related to slightly different electrospray conditions in the two experiments. The separation of the two peaks that are centered at the lowest $C V$ values is nearly the same $( \pm 0.1 \mathrm{~V})$ in both experiments. Similar matches are observed for the $9+$ through $12+$ charge states, with our CV scans for the $10+$ and $12+$ charge states indicating two unresolved conformers $^{\circ}\left(\text { Figure }^{\circ} 2\right)^{\circ}$ versus $^{\circ}$ three ${ }^{\circ}$ and $^{\circ}$ two $^{\circ}$ resolved conformers reported by Purves et al. for these respective ions. From these results, it is possible to relate $\mathrm{CV}$ values measured for various conformers of different charge states to the physical cross sections of these ions. For example, the two $8+$ conformers that are transmitted at $C V$ values of -4.4 and $-6.0 \mathrm{~V}$ have cross sections of 1585 and $1330 \AA^{2}$, respectively. By comparison, the crystal structure of ubiquitin has a cross section of 930 $\AA^{2}$ and a fully extended structure has a cross section of $2140 \AA^{2}[9 b, 10 c]$.

\section{FAIMS with H/D Exchange}

Experiments combining FAIMS with H/D exchange were done to determine how the extent of $\mathrm{H} / \mathrm{D}$ exchange correlates with the collisional cross section of an ion. $\mathrm{H} / \mathrm{D}$ exchange results $(20 \mathrm{~s})$ for the $8+$ charge state measured at four different $\mathrm{CV}$ values are shown in
Figure 3. The $^{\circ} \mathrm{CV}^{\circ}$ values ${ }^{\circ} f^{\circ}-4.4,{ }^{\circ}-5.4,-6.0,{ }^{\circ}$ and $^{\circ}-6.4^{\circ} \mathrm{V}$ correspond to ion cross sections of 1585, 1410, 1330, and $1280 \AA^{2}$, respectively. As can be seen from the H/D exchange ${ }^{\circ}$ data $^{\circ}$ in $^{\circ}$ Figure $^{\circ} 3,{ }^{\circ}$ two $^{\circ}$ distinct $^{\circ}$ conformers ${ }^{\circ}$ or families of unresolved conformers, centered around 6 and 18 incorporated deuteriums, are resolved using $\mathrm{H} / \mathrm{D}$ exchange at each of these $\mathrm{CV}$ values (the slightly higher ${ }^{\circ}$ extent ${ }^{\circ}$ of ${ }^{\circ}$ exchange ${ }^{\circ}$ in ${ }^{\circ}$ Figure ${ }^{\circ}{ }^{\circ} a,{ }^{\circ} b^{\circ}$ versus ${ }^{\circ}{ }^{\circ},{ }^{\circ}{ }^{\circ}$ is an artifact attributable to slightly higher pressures of gaseous $\mathrm{D}_{2} \mathrm{O}$ ). There is no obvious change in the abundance of these two conformer families as measured by $\mathrm{H} / \mathrm{D}$ exchange despite the significantly different physical cross sections of the ions at the different $C V$ values. These results clearly demonstrate that the two conformer families that are resolved using FAIMS have essentially the same H/D exchange extents. Similarly, $\mathrm{H} / \mathrm{D}$ exchange resolves two families of conformers that are not resolved using FAIMS. These results indicate that $\mathrm{H} / \mathrm{D}$ exchange is sensitive to conformational differences between these ion populations that is not directly related to the collisional cross sections of these ions, or that the ion populations undergo isomerizations to two different conformations on the long time frame of the H/D exchange experiments.

Results of the FAIMS-H/D exchange experiments for the $9+$ charge state are shown for both 20 and $40 \mathrm{~s}$ reaction ${ }^{\circ}$ times ${ }^{\circ}$ in ${ }^{\circ}$ Figure ${ }^{\circ} 4 .{ }^{\circ} \mathrm{A}$ broad ${ }^{\circ}$ peak ${ }^{\circ}$ in the ${ }^{\circ} \mathrm{CV}^{\circ}$ scan is observed indicating the presence of two or more largely ${ }^{\circ}$ unresolved ${ }^{\circ}$ conformers $^{\circ}\left(\right.$ Figure $\left.^{\circ} 4 a\right) .{ }^{\circ}$ Maxima ${ }^{\circ}$ in the $\mathrm{CV}$ data occur at -5.8 and $-5.0 \mathrm{~V}$. These values are within $0.1 \mathrm{~V}$ of those for the two peaks observed by Purves $^{\circ}$ et $^{\circ}$ al. $^{\circ}[14]^{\circ}$ who $^{\circ}$ reported ${ }^{\circ}$ better $^{\circ}$ resolved $^{\circ}$ peaks with collisional cross sections for the constituent ions of 1460 and $1625 \AA^{2}$, respectively. H/D exchange data
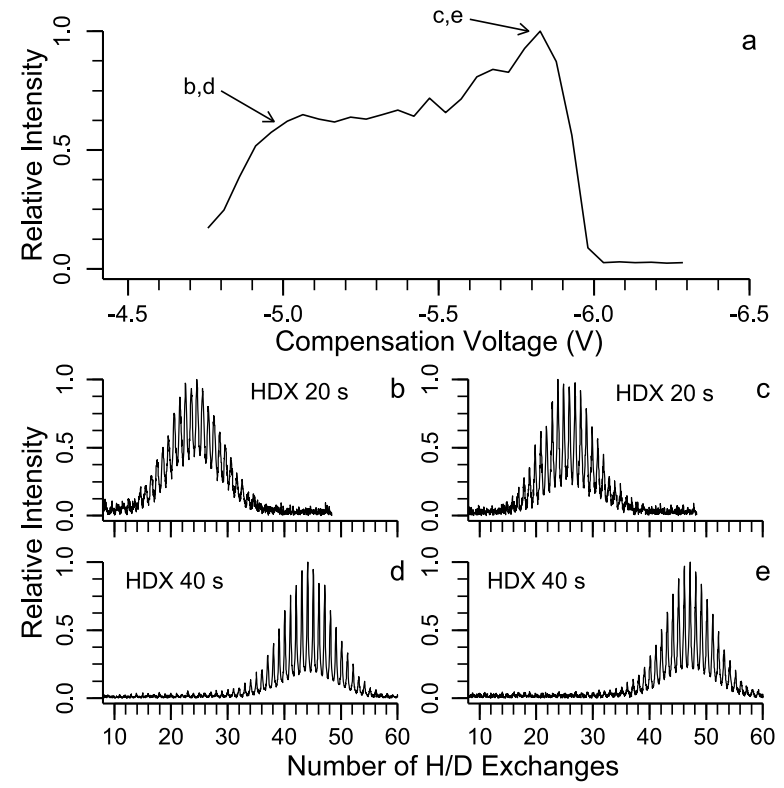

Figure 4. FAIMS-FT/ICR MS data for the $9+$ charge state of ubiquitin: (a) CV scan and (b), (c), (d), (e) H/D exchange measured at $\mathrm{CV}$ values of $-5.0 \mathrm{~V}(\mathbf{b}),(\mathbf{d})$ and $-5.8 \mathrm{~V}(\mathbf{c}),(\mathbf{e})$ at $20 \mathrm{~s}(\mathbf{b})$, (c) and $40 \mathrm{~s}$ exchange time (d), (e). 

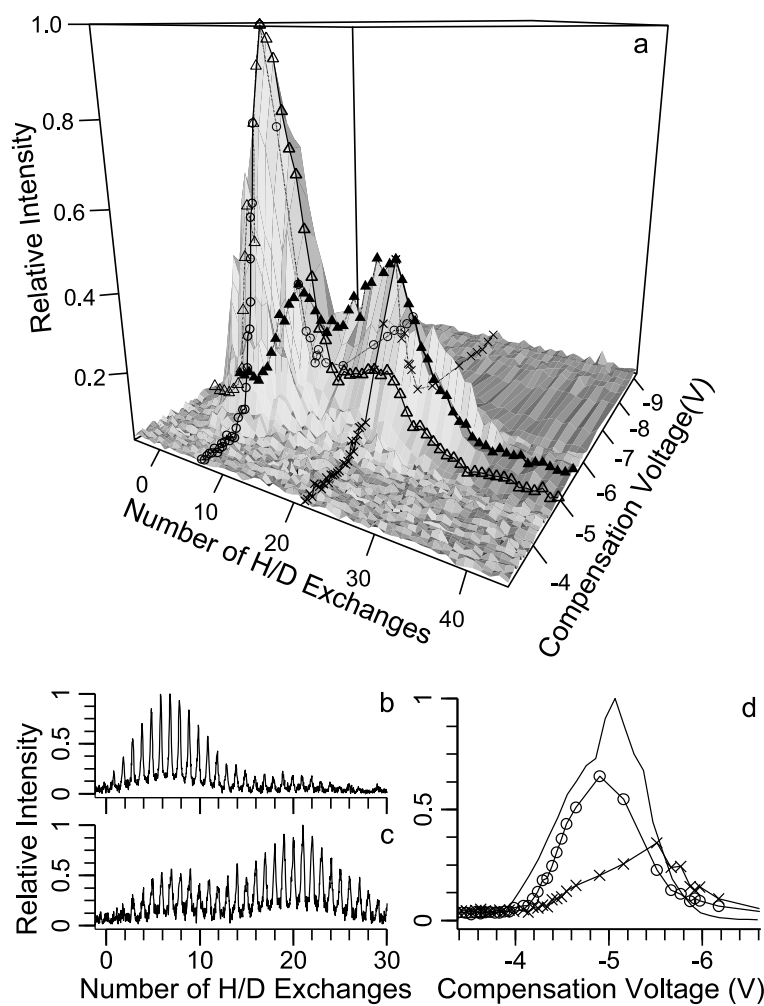

Figure 5. FAIMS-FT/ICR MS data for the $10+$ charge state of bovine ubiquitin measured using $20 \mathrm{~s} \mathrm{H} / \mathrm{D}$ reaction time: (a) surface plot of $C V$ values versus extents of $H / D$ exchange, where lines marked with open triangles and filled triangles indicate H/D exchange distributions at $\mathrm{CV}$ values of $-4.9 \mathrm{~V}$ and $-5.5 \mathrm{~V}$, respectively, and lines marked with open circles and letters $x$ correspond to CV scans of the H/D exchange distribution with 7 and 21 deuteriums incorporated, respectively, (b) and (c) H/D exchange mass spectra at $-4.9 \mathrm{~V}(\mathbf{b})$ and $-5.5 \mathrm{~V}$ (c) and (d) $\mathrm{CV}$ scan with no $\mathrm{H} / \mathrm{D}$ exchange (solid line) and with $\mathrm{H} / \mathrm{D}$ exchange of the conformer that undergoes 7 exchanges (open circles) and 21 exchanges (letters $\mathrm{x}$ ).

measured ${ }^{\circ} a^{\circ}{ }^{\circ}$ hese ${ }^{\circ}$ two $^{\circ} \mathrm{CV}^{\circ}$ values ${ }^{\circ}$ are $^{\circ}$ shown $^{\circ}$ in ${ }^{\circ}$ Figure $4 \mathrm{~b}-\mathrm{Q}$. ${ }^{\circ}$ Both ${ }^{\circ}$ at $20^{\circ} \mathrm{s}^{\circ} \mathrm{and}^{\circ} \mathrm{at}^{\circ} 40^{\circ} \mathrm{s}, \mathrm{a}^{\circ}{ }^{\circ}$ single ${ }^{\circ}$ isotope ${ }^{\circ}$ distribution is observed corresponding to an average of 24 and 48 deuteriums incorporated, respectively. Prior H/D exchange ${ }^{\circ}$ experiments ${ }^{\circ}\left(\text { Table }^{\circ} 1\right)^{\circ}$ did $^{\circ}$ resolve $^{\circ} \mathrm{a}^{\circ}$ second lower exchanging distribution at $40 \mathrm{~s}$ of $\mathrm{H} / \mathrm{D}$ exchange. Marshall and coworkers also reported a lower exchanging $^{\circ}$ distribution ${ }^{\circ}$ for ${ }^{\circ}$ this ${ }^{\circ}$ charge $^{\circ}$ state $^{\circ}[4]$. .The $^{\circ}$ low ${ }^{\circ}$ abundance of this distribution makes this conformation difficult to detect consistently. In contrast, the FAIMS results indicate that at least two conformers are initially present in similar abundance. This could be due to the presence of multiple conformers that are stable on the lifetime of the FAIMS measurements (hundreds of ms [26]), ${ }^{\circ}$ but $^{\circ}$ which $^{\circ}$ isomerize ${ }^{\circ}$ to ${ }^{\circ} \mathrm{a}^{\circ}$ single $^{\circ}$ conformer $^{\circ}$ (or unresolved family of conformers) on a time frame much shorter than the $\mathrm{H} / \mathrm{D}$ exchange reaction time (tens of s). Another possible explanation for this result is that the conformers that have different physical cross sections undergo the same extent and rate of H/D exchange.

Results ${ }^{\circ}$ for ${ }^{\circ}$ the $10+{ }^{\circ}$ charge $^{\circ}$ state ${ }^{\circ}$ are ${ }^{\circ}$ shown ${ }^{\circ}{ }^{\circ}$ Figure 5. ${ }^{\circ}$ The ${ }^{\circ}$ surface ${ }^{\circ}$ plot $^{\circ}$ of $^{\circ}$ the ${ }^{\circ} \mathrm{H} / \mathrm{D}^{\circ}$ exchange ${ }^{\circ}$ and ${ }^{\circ} \mathrm{CV}^{\circ}$ scan data $^{\circ}$ in $^{\circ}$ Figure $^{\circ} 5 a^{\circ}$ indicates $^{\circ}$ two $^{\circ}$ local $^{\circ}$ maxima. ${ }^{\circ}$ These maxima occur at $\mathrm{CV}$ values of -4.9 and $-5.5 \mathrm{~V}$ with 7 and $21^{\circ}$ deuteriums ${ }^{\circ}$ incorporated, respectively. In Figure $5 b^{\circ}$ and ${ }^{\circ} \mathrm{C}^{\circ}$ the ${ }^{\circ} \mathrm{H} / \mathrm{D}^{\circ}$ exchange $^{\circ}$ data $^{\circ}{ }^{\circ}{ }^{\circ} \mathrm{CV}^{\circ}{ }^{\circ}$ values ${ }^{\circ}$ of ${ }^{\circ}-4.9$ and $-5.5 \mathrm{~V}$ clearly show two resolved conformers, the relative abundances of which depend on the $C V$ values. At a CV of $-4.9 \mathrm{~V}$, the abundance of the conformer that undergoes 7 exchanges is 3.9 times greater than that of the conformer that undergoes 21 exchanges. At a CV of $-5.5 \mathrm{~V}$, the abundance of the lower exchanging conformer is only 0.8 times that of the higher exchanging conformer. ${ }^{\circ}$ From $^{\circ}$ the ${ }^{\circ}$ surface ${ }^{\circ}$ plot $^{\circ}$ data $^{\circ}$ in $^{\circ}$ Figure $^{\circ} 5$ a, individual $\mathrm{CV}$ scans are constructed for the two conformers ${ }^{\circ}$ resolved ${ }^{\circ}$ by $^{\circ} \mathrm{H} / \mathrm{D}^{\circ}$ exchange $^{\circ}\left(\right.$ Figure $\left.^{\circ} 5 \mathrm{~d}\right) .^{\circ}$ The conformers that undergo 7 and 21 exchanges have maxima at $C V$ values of -4.9 and $-5.5 \mathrm{~V}$, respectively. Also ${ }^{\circ}$ shown ${ }^{\circ}{ }^{\circ}{ }^{\circ}$ Figure $^{\circ} 5 \mathrm{~d}^{\circ}{ }^{\circ} \mathrm{s}^{\circ}$ the ${ }^{\circ} \mathrm{CV}^{\circ}$ scan $^{\circ}{ }^{\circ}$ without ${ }^{\circ} \mathrm{H} / \mathrm{D}$ exchange. This CV scan with no $\mathrm{H} / \mathrm{D}$ exchange has a broad peak with no obviously resolved conformers. Purves et al. reported two unresolved conformations for this charge state with a maximum at $-5.35 \mathrm{~V}$ and the second conformation identified as a shoulder on the main peak at $-4.95 \mathrm{~V}$, consistent with our $\mathrm{H} / \mathrm{D}$ exchange resolved $\mathrm{CV}$ scans.

From $^{\circ}$ the ${ }^{\circ}$ Figure $^{\circ} 5^{\circ}$ data, ${ }^{\circ}$ clearly ${ }^{\circ}$ the ${ }^{\circ}$ two ${ }^{\circ}$ conformers that undergo different extents of $\mathrm{H} / \mathrm{D}$ exchange also have different collisional cross sections. Purves et al. measured cross sections of 1710 and $1670 \AA^{2}$ for ions transmitted at $C V$ values of -4.95 and $-5.35 \mathrm{~V}$, respectively. By comparison to these results, the conformer that undergoes 7 exchanges corresponds to an ion with a cross section of $\sim 1710 \AA^{2}$ and the conformer that undergoes 21 exchanges corresponds to an ion with a
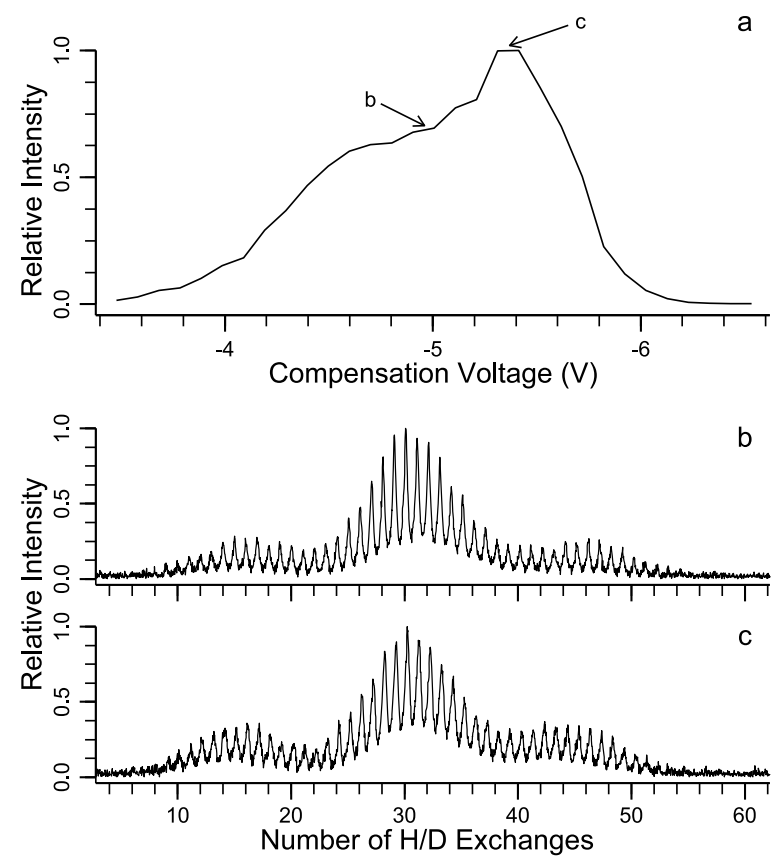

Figure 6. FAIMS-FT/ICR MS data for the $11+$ charge state of bovine ubiquitin: (a) CV scan and spectra obtained at $C V$ values of (b) $-5.0 \mathrm{~V}$ and (c) $-5.4 \mathrm{~V}$ with $40 \mathrm{~s}$ reaction time. 
physical cross section of $\sim 1670 \AA^{2}$. Thus, the ion with the larger physical cross section undergoes less H/D exchange.

The CV scan for the $11+$ charge state of ubiquitin has a peak at $-5.4 \mathrm{~V}$ and a broad shoulder around -4.7 to $-5.0 \mathrm{~V}$ indicating the presence of at least two conformations $^{\circ}\left(\right.$ Figure $\left.^{\circ} 6 \mathrm{a}\right) .{ }^{\circ}$ Purves $^{\circ}$ et $^{\circ}$ al. ${ }^{\circ}$ measured $^{\circ}$ collisional cross sections of 1755 and $1770 \AA^{2}$ at $C V$ values of -5.35 and $^{\circ}-5.0^{\circ} \mathrm{V},{ }^{\circ}$ respectively. ${ }^{\circ} \mathrm{In}^{\circ}$ Figure $^{\circ} 6 \mathrm{~b}^{\circ}$ and $^{\circ} \mathrm{c}^{\circ}{ }^{\circ} \mathrm{H} / \mathrm{D}$ exchange spectra ( $40 \mathrm{~s}$ ) are shown at $\mathrm{CV}$ values of -5.0 and $-5.4 \mathrm{~V}$. Three conformations are resolved by H/D exchange with average deuterium incorporation of 16 , 30, and 45. The H/D distributions for this charge state do not change at different $\mathrm{CV}$ values. FAIMS results indicate at least two conformations and H/D exchange independently resolves three conformations.

A CV scan (no H/D exchange) for the $12+$ charge state shows a single broad peak with a maximum at $-4.4^{\circ} \mathrm{V}^{\circ}$ (Figure $\left.{ }^{\circ} 7 \mathrm{a}\right)^{\circ} \mathrm{H} / \mathrm{D}^{\circ}$ exchange $^{\circ}\left(20^{\circ} \mathrm{s}\right)^{\circ}$ resolves ${ }^{\circ}$ two conformations with 2 and 17 deuteriums incorporated.

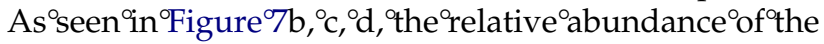
two distributions resolved by $\mathrm{H} / \mathrm{D}$ exchange depend on the $\mathrm{CV}$ value. The relative abundance of the conformer that undergoes less exchange is greatest at -4.2 $\mathrm{V}^{\circ}$ (Figure $\left.{ }^{\circ} 7 \mathrm{~b}\right) .^{\circ}$ The $^{\circ}$ conformer $^{\circ}$ that $^{\circ}$ undergoes $^{\circ}$ more exchange has a relative intensity maximum at $-5.1 \mathrm{~V}$ (Figure $\left.{ }^{\circ} 7 \mathrm{~d}\right) .{ }^{\circ}$ Figure $^{\circ} 7 \mathrm{c}^{\circ}$ shows $^{\circ} \mathrm{a}^{\circ}$ mass $^{\circ}$ spectrum $^{\circ}$ at $^{\circ}$ an intermediate voltage of $-4.6 \mathrm{~V}$. A spectrum of the $12+$ charge state with no exchange is shown for reference in Figure 7 e.

Individual $\mathrm{CV}$ plots for both conformers resolved by $\mathrm{H} / \mathrm{D}$ exchange can be reconstructed from these data
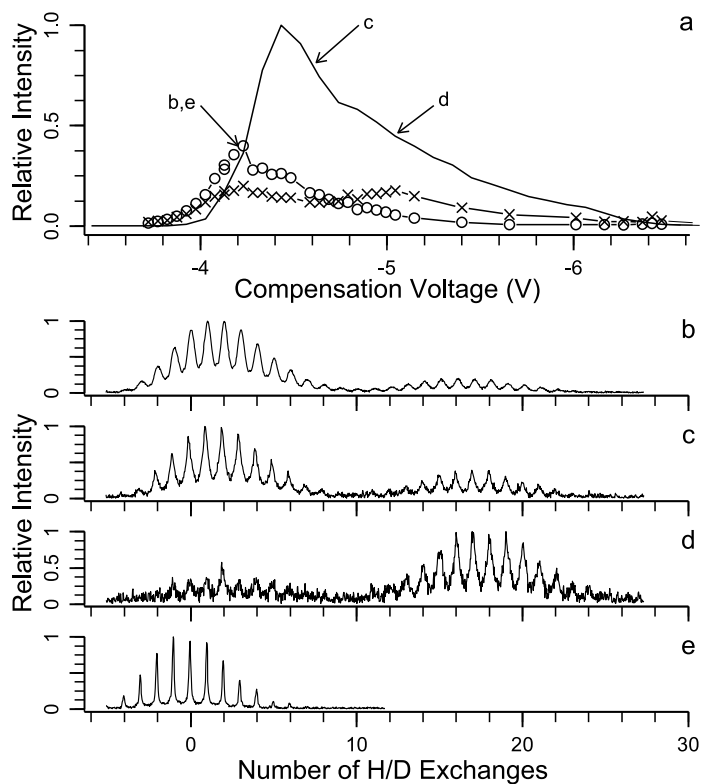

Figure 7. FAIMS-FT/ICR MS data for the $12+$ charge state of bovine ubiquitin: (a) CV scan with no H/D exchange (solid line), conformer with 17 exchanges (letter $\mathrm{x}$ ), and conformer with 2 exchanges (open circles) where b, c, d, and e indicate the compensation voltages at which the $H / D$ exchange mass spectra were acquired (20 s reaction time for (b)-(d), no H/D exchange for (e). and $^{\circ}$ are $^{\circ}$ shown $^{\circ}$ in $^{\circ}$ Figure $^{\circ} 7 \mathrm{a}^{\circ}{ }^{\circ}$ The $^{\circ} \mathrm{CV}^{\circ}$ plot $^{\circ}$ for ${ }^{\circ}$ the conformer ${ }^{\circ}$ that ${ }^{\circ}$ undergoes ${ }^{\circ}$ less ${ }^{\circ}$ exchange $^{\circ}(2)^{\circ}$ has $^{\circ} a^{\circ}$ maximum in CV transmission at $-4.2 \mathrm{~V}$. The CV scan of the conformerthat ${ }^{\circ}$ undergoes ${ }^{9}$ more $^{\circ} \mathrm{H} / \mathrm{D}^{\circ}$ exchange $^{\circ}(17)$ has peaks at $C V$ values of -4.2 and $-5.1 \mathrm{~V}$. This $\mathrm{CV}$ scan is similar to the $\mathrm{CV}$ scan obtained by Purves et al. who resolved two peaks at $C V$ values of -4.55 and $-5.05 \mathrm{~V}$ with measured collisional cross sections of 1905 and $1890 \AA^{2}$, respectively. These results suggest that at least three conformers are present for the $12+$ charge state. The two conformers that have a single measured cross section of $1905 \AA^{2}$, correspond to H/D exchange distributions with 2 and 17 deuteriums incorporated. The ions with a more compact conformation or lower cross section of $1890 \AA^{2}$ correspond to a third conformer that also undergoes $17 \mathrm{H} / \mathrm{D}$ exchanges. As observed for the $10+$ charge state, a more compact conformer can undergo greater extent of $\mathrm{H} / \mathrm{D}$ exchange.

For the $13+$ charge state with $20 \mathrm{~s}$ of H/D exchange, one distribution is observed with no deuteriums incorporated. We were unable to determine the extent of exchange at longer exchange times because of insufficient S/N. Marshal and coworkers also observed a single exchange distribution with 12 deuteriums incorporated ${ }^{\circ}$ at $^{\circ} 3600^{\circ} \mathrm{s}^{\circ}[4]^{\circ}{ }^{\circ} \mathrm{The}^{\circ} \mathrm{CV}^{\circ} \mathrm{scan}^{\circ}$ of ${ }^{\circ}$ the ${ }^{\circ} 13+{ }^{\circ}$ charge state has one peak at $-4.6 \mathrm{~V}$. Purves et al. also observed a single peak for the $13+$ charge state at $-4.65 \mathrm{~V}$ and this ion has a measured cross section of $1970 \AA^{2}$. Multiple conformations for the $13+$ have been resolved with FAIMS using a different carrier gas composition of $60 / 40$ helium/nitrogen gas [20b]. McLafferty and coworkers also reported evidence of multiple conformations for the $13+$ charge state based on evidence from ECD experiments [15d]. The $13+$ charge state has the largest measured cross section, presumably due to having the most extended conformation, but this ion undergoes the least H/D exchange (at $20 \mathrm{~s}$ ) of the charge states investigated. Presumably, this ion has the greatest surface accessibility, but undergoes the least $\mathrm{H} / \mathrm{D}$ exchange.

\section{Conclusions}

For the ubiquitin ions of a given charge state, the extents of H/D exchange at short times (20-40 s) do not appear to be significantly correlated to ion cross sections. For the $8+, 9+$, and $11+$ charge states, the extents of $\mathrm{H} / \mathrm{D}$ exchange do not depend on FAIMS CV values, but those of the $10+$ and $12+$ charge states do. For the latter charge states, the conformations that undergo the greatest extent of $\mathrm{H} / \mathrm{D}$ exchange occur at $\mathrm{CV}$ values corresponding to conformations with lower cross section. This indicates that more compact conformers can undergo greater extents of H/D exchange. Factors other than surface accessibility or cross section appear to play an important role in determining the rate and extent of $\mathrm{H} / \mathrm{D}$ exchange within these charge states. This result is consistent with the observation that $\mathrm{H} / \mathrm{D}$ exchange 
extents of peptide dimers can be greater or less than those of the constituent monomers [16a].

Previously proposed mechanisms for $\mathrm{H} / \mathrm{D}$ exchange indicate that an $\mathrm{H} / \mathrm{D}$ exchange reagent, such as $\mathrm{D}_{2} \mathrm{O}$, must form two simultaneous hydrogen bonds before

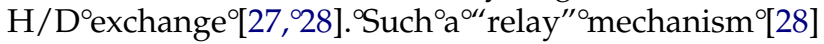
suggests that the observed decrease in H/D exchange for more extended conformers of a given charge state may be attributable to fewer possible multi-dentate interactions with the $\mathrm{D}_{2} \mathrm{O}$.

Others have suggested that ubiquitin conformers with different charge states can be grouped into "families" of structures based on either collisional cross section or on H/D exchange extents. Although conformers with different charge states may be structurally very similar, our combined FAIMS and H/D exchange measurements suggest that grouping conformers into families based on a single physical property may oversimplify the complexity of these gas-phase conformers. FAIMS and H/D exchange can each resolve gas-phase conformations that are not resolved by the other technique and a combination of FAIMS and H/D exchange resolves more conformers than either method alone. These results suggest that H/D exchange and collision cross sectional measurements probe different properties of the gas-phase ubiquitin conformers. For the 12+ charge state, the two conformers (or conformer populations) have cross sections that differ by $<1 \%$, yet the $\mathrm{H} / \mathrm{D}$ exchange extents (40 s) of these two conformers differ significantly (6 versus 25 ). For the $9+$ charge state, the cross sections of the two conformers differ by $10 \%$, yet only one conformer is observed by $\mathrm{H} / \mathrm{D}$ exchange. There is the possibility that the longer time frame $H / D$ exchange experiments probe the gas-phase conformations of the ubiquitin ions after they have isomerized to conformations not present during the time in which ions are transmitted through the FAIMS device. However, the dependence of H/D exchange on compensation voltage for the $10+$ and $12+$ charge states implies that at least some of the conformers originally separated by FAIMS survive and are probed by these H/D exchange experiments. Thus, the combination of FAIMS and H/D exchange provides a nearly orthogonal two-dimensional separation of the ubiquitin conformers.

\section{Acknowledgments}

The authors thank Dr. Roger Guevremont and Dr. Randy W. Purves for helpful discussions, and for generously sharing their expertise with FAIMS. The authors are grateful to Ionalytics Corporation for the loan of an Ionalytics Selectra FAIMS apparatus and to NIH for generous funding (R01-GM64712).

\section{References}

1. (a) Onuchic, J. N.; LutheySchulten, Z.; Wolynes, P. G. Theory of Protein Folding: The Energy Landscape Perspective. Annu. Rev. Phys. Chem. 1997, 48, 545-600. (b) Onuchic, J. N.; Wolynes, P. G. Theory of Protein Folding. Curr. Opin. Struct. Biol. 2004,
14, 70-75. (c) Kubelka, J.; Hofrichter, J.; Eaton, E. A. The Protein Folding "Speel Limit". Curr. Opin. Struct. Biol. 2004, 14, $76-88$.

2. Jarrold, M. F. Peptides and Proteins in the Vapor Phase. Ann. Rev. Phys. Chem. 2000, 51, 179-207.

3. (a) Suckau, D.; Shi, Y.; Beu, S. C.; Senko, M. W.; Quinn, J. P.; Wampler, F. M.; McLafferty, F. W. Coexisting Stable Conformations of Gaseous Protein Ions. Proc. Natl. Acad. Sci. U.S.A. 1993, 90, 790-793. (b) McLafferty, F. W.; Guan, Z.; Haupts, U.; Wood, T. D.; Kelleher, N. L.; Gaseous Conformational Structures of Cytochrome c. J. Am. Chem. Soc. 1998, 120, 4732-4740. (c) Wood, T. D.; Chorush, R. A.; Wampler, F. M.; Little, D. P.; O'Connor, P. B.; McLafferty, F. W. Gas-Phase Folding and Unfolding of Cytochrome $c$ Cations. Proc. Natl. Acad. Sci. U.S.A. 1995, 92, 2451-2454.

4. Freitas, M. A.; Hendrickson, C. L.; Emmett, M. R.; Marshall, A. G. Gas-Phase Bovine Ubiquitin Cation Conformations Resolved by Gas-Phase Hydrogen/Deuterium Exchange Rate and Extent. Int. J. Mass Spectrom. 1999, 185/186/187, 565-575.

5. Winger, B. E.; Light-Wahl, K. J.; Rockwood, A. L.; Smith, R. D. Probing Qualitative Conformation Differences of Multiply Protonated Gas-Phase Proteins via H/D Isotopic Exchange with $\mathrm{D}_{2}$ O. J. Am. Chem. Soc. 1992, 114, 5897-5898.

6. (a) Geller, O; Lifshitz, C. A Fast Flow Tube Study of Gas-Phase H/D Exchange of Multiply Protonated Ubiquitin. J. Phys. Chem. A 2005, 109, 2217-2222. (b) Evans, S. E.; Lueck, N.; Marzluff, E. M. Gas-Phase Hydrogen/Deuterium Exchange of Proteins in an Ion Trap Mass Spectrometer. Int. J. Mass Spectrom. 2003, 222, 175-187. (c) Geller, O.; Lifshitz, C. Hydrogen/Deuterium Exchange Kinetics of Cytochrome $c$ : An Electrospray Ionization Fast Flow Experiment. Isr. J. Chem. 2003, 43, 347-352. (d) Valentine, A. E.; Clemmer, D. E. TemperatureDependent H/D Exchange of Compact and Elongated Cytochrome $c$ Ions in the Gas Phase. J. Am. Soc. Mass Spectrom. 2002, 13, 506-517. (e) Wang, F.; Freitas, M. A.; Marshall, A. G.; Sykes, B. D. Gas-Phase Memory of Solution-Phase Protein Conformation: H/D Exchange and Fourier Transform Ion Cyclotron Resonance Mass Spectrometry of the N-Terminal Domain of Cardiac Troponin c. Int. J. Mass Spectrom. 1999, 192; 319-325. (f) Wagner, D. S.; Anderegg, R. J. Conformation of Cytochrome $c$ Studied by Deuterium Exchange Electrospray Ionization Mass Spectrometry. Anal. Chem. 1994, 66, 706-711.

7. (a) Clemmer, D. E.; Hudgins R. R.; Jarrold, M. F. Naked Protein Conformations-Cytochrome $c$ in the Gas Phase. J. Am. Chem. Soc. 1995, 117, 10141-10142. (b) Hudgins, R. R.; Woenckhaus, J.; Jarrold, M. F. High Resolution Ion Mobility Measurements for Gas-Phase Proteins: Correlation Between Solution-Phase and Gas-Phase Conformations. Int. J. Mass Spectrom. 1997, 165, 497-507.

8. (a) Wyttenbach, T.; vonHelden, G.; Bowers, M. T. Gas-Phase Conformation of Biological Molecules: Bradykinin. J. Am. Chem. Soc. 1996, 118, 8355-8364. (b) Wyttenbach, T.; Kemper, P. R.; Bowers, M. T. Int. J. Mass Spectrom. 2002, 212, 13.

9. (a) Badman, E. R.; Hoaglund-Hyzer, C. S.; Clemmer, D. E. Monitoring Structural Changes of Proteins in an Ion Trap Over $\sim 10$ to $200 \mathrm{~ms}$ : Unfolding Transitions in Cytochrome $c$ Ions. Anal. Chem. 2001, 73, 6000-6007. (b) Myung, S.; Badman, E. R.; Lee, Y. J.; Clemmer D. E. Structural Transitions of Electrosprayed Ubiquitin Ions Stored in an Ion Trap over $\sim 10$ ms to 30 s. J. Phys. Chem. A 2002, 106, 9976-9982. (c) Li, J.; Taraszka, J. A.; Counterman, A. E.; Clemmer D. E. Influence of Solvent Composition and Capillary Temperature on the Conformations of Electrosprayed Ions: Unfolding of Conpact Ubiquitin Conformers from Pseudonative and Denatured Solutions. Int. J. Mass Spectrom. 1999, 185/186/187, 37-47. (d) Valentine, S. J.; Anderson, J. G.; Ellington A. D.; Clemmer, D. E. Disulfide-Intact and -Reduced Lysozyme in the Gas 
Phase: Conformations and Pathways of Folding and Unfolding. J. Phys. Chem. B 1997, 101, 3891-3900.

10. (a) Gross, D. S.; Schnier, P. D.; Rodriguez-Cruz, S. E.; Fagerquist, C. K.; Williams, E. R. Conformations and Folding of Lysozyme Ions in Vacuo. Proc. Natl. Acad. Sci. U.S.A. 1996, 93, 3143-3148. (b) Zhang, X.; Cassady, C. J.; Apparent Gas-Phase Acidities of Multiply Protonated Peptide Ions: Ubiquitin, Insulin B, and Renin Substrate. J. Am. Soc. Mass Spectrom. 1996, 7, 1211-1218. (c) Valentine, S. J.; Counterman, A. E.; Clemmer. D. E. Conformer-Dependent Proton Transfer Reactions of Ubquitin Ions. J. Am. Soc. Mass. Spectrom. 1997, 8, 954-961. (d) Loo, R. R. O.; Loo, J. A.; Udseth, H. R.; Fulton, J. L.; Smith, R. D. Protein Structural Effects in Gas-Phase Ion Molecule Reactions with Diethylamine. Rapid Commun. Mass Spectrom. 1992, 6, 159-165.

11. (a) Reimann, C. T.; Sullivan, P. A.; Axelsson, J.; Quist, A. P.; Altmann, S.; Roepstorff, P.; Velazquez, I.; Tapia, O. Conformation of Highly-Charged Gas-Phase Lysozyme Revealed by Energetic Surface Imprinting. J. Am. Chem. Soc. 1998, 120, 7608-7616. (b) Sullivan, P. A.; Axelsson, J.; Altmann, S.; Quist, A. P.; Sunqvist, B. U. R.; Reimann, C. T. Defect Formation on Surfaces Bombarded by Energetic Multiply Charged Proteins: Implications for the Conformation of Gas-Phase Electrosprayed Ions. J. Am. Soc. Mass Spectrom. 1996, 7, 329-341.

12. (a) Arteca, G. A.; Reimann, C. T.; Tapia, O. Proteins in Vacuo: Denaturing and Folding Mechanisms Studied with ComputerSimulated Molecular Dynamics. Mass Spectrom. Rev. 2001, 20, 402-422. (b) Mao, Y.; Ratner, M. A.; Jarrold, M. F. Molecular Dynamics Simulations of the Charge-Induced Unfolding and Refolding of Unsolvated Cytochrome c. J. Phys. Chem. B 1999, 103, 10017-10021. (c) Liu, D. F.; Wyttenbach, T.; Carpenter, C. J.; Bowers, M. T. Investigation of Noncovalent Interactions in Deprotonated Peptides: Structural and Energetic Competition Between Aggregation and Hydration. J. Am. Chem. Soc. 2004, 126, 3261-3270.

13. (a) Covey, T.; Douglas, D. J. Collision Cross-Sections for Protein Ions. J. Am. Soc. Mass Spectrom. 1993, 4, 616-623. (b) Cox, K, A.; Julian, R. K.; Cooks, R. G.; Kaiser, R. E. Conformer Selection of Protein Ions by Ion Mobility in a Triple Quadrupole Mass-Spectrometer. J. Am. Soc. Mass Spectrom. 1994, 5, 127-136. (c) Moradian, A.; Scalf, M.; Westphall, M. S.; Smith, L. M.; Douglas, D. J. Collision Cross-Sections of Gas-Phase DNA Ions. Int. J. Mass Spectrom. 2002, 219, 161-170.

14. Purves, R. W.; Barnett, D. A.; Ells, B.; Guevremont, R. Investigation of Bovine Ubiquitin Conformers Separated by HighField Asymmetric Waveform Ion Mobility Spectrometry: Cross Section Measurements Using Energy-Loss Experiments with a Triple Quadrupole Mass Spectrometer. J. Am. Soc. Mass Spectrom. 2000, 11, 738-745.

15. (a) Wu, G. Y.; Van Orden, S.; Cheng, X. H.; Bakhtiar, R.; Smith, R. D. Characterization of Cytochrome-c Variants with HighResolution FT/ICR Mass Spectrometry-Correlation of Fragmentation and Structure. Anal. Chem. 1995, 67, 2498-2509. (b) Cassady, C. J.; Carr, S. R. Elucidation of Isomeric Structures for Ubiquitin $[\mathrm{M}+12 \mathrm{H}](12+)$ Ions Produced by Electrospray Ionization Mass Spectrometry. J. Mass Spectrom. 1996, 31, 247-254. (c) Kaltashov, I. A.; Fenselau, C. Stability of Secondary Structural Elements in a Solvent-Free Environment: The Alpha Helix. Proteins: Struct., Funct., Genet. 1997, 27, 165-170. (d) Breuker, K.; Oh, H.; Horn, D. M.; Cerda, B. A.; McLafferty, F. W. Detailed Unfolding and Folding of Gaseous Ubiquitin Ions Characterized by Electron Capture Dissociation. J. Am. Chem. Soc. 2002, 124, 6407-6420. (e) Badman, E. R.; Myung S.; Clemmer D. E. Dissociation of Different Conformations of Ubquitin Ions. J. Am. Soc. Mass Spectrom. 2002, 13, 719-723. (f) Van Den Bremer, E. T. J.; Jiskoot, W.; James, R.; Moore, G. R.; Kleanthous, C.; Heck, A. J. R.; Maier, C. S. Probing Metal Ion
Binding and Conformational Properties of the Colicin E9 Endonuclease by Electrospray Time-of-Flight Mass Ionization Spectrometry. Protein Sci. 2002, 11, 1738-1752. (g) Oh, H.; Breuker, K.; Sze, S. K.; Ge, Y.; Carpenter, B. K.; McLafferty, F. W. Secondary and Tertiary Structures of Gaseous Protein Ions Characterized by Electron Capture Dissociation Mass Spectrometry and Photofragment Spectroscopy. Proc. Natl. Acad. Sci. U.S.A. 2002, 99, 15863-15868.

16. (a) Jurchen, J. C.; Cooper, R. E.; Williams, E. R. The Role of Acidic Residues and of Sodium Ion Adduction on the GasPhase H/D Exchange of Peptides and Peptide Dimers. J. Am. Soc. Mass Spectrom. 2003, 14, 1477-1487. (b) Cox, H. A.; Julian, R. R.; Sang-Won, L.; Beauchamp, J. L. Gas-Phase H/D exchange of Sodiated Glycine Oligomers with ND3: Exchange Kinetics Do Not Reflect Parent Ion Structures. J. Am. Chem. Soc. 2004, 126, 6485-6490. (c) Freitas, M. A.; Marshall, A.G. Rate and Extent of Gas-Phase Hydrogen/Deuterium Exchange of Bradykinins: Evidence for Peptide Zwitterions in the Gas Phase. Int. J. Mass Spectrom. 1999, 183, 221-231.

17. (a) Bowers, M. T.; Kemper, P. R.; von Helden G.; van Koppen, P. A. M. Gas-Phase Ion Chromatography-Transition-Metal State Selection and Carbon Cluster Formation. Science 1993, 260, 1446-1451. (b) Clemmer, D. E.; Jarrold, M. F. Ion Mobility Measurements and Their Applications to Clusters and Biomolecules. J. Mass Spectrom. 1997, 32, 577-592.

18. Valentine, S. J.; Clemmer, D. E. H/D Exchange Levels of Shape-Resolved Cytochrome $c$ Conformers in the Gas Phase. J. Am. Chem. Soc. 1997, 119, 3558-3566.

19. (a) Buryakov, I. A.; Krylov, E. V.; Nazarov, E. G.; Rasulev, U. K. A New Method of Separation of Multi-Atomic Ions by Mobility at Atmospheric Pressure Using a High-Frequency Amplitude-Asymmetric Strong Electric Field. Int. J. Mass Spectrom. Ion Processes 1993, 128, 143-148. (b) Buryakov, I. A.; Krylov, E. V.; Makas, A. L.; Nazarov, E. G.; Pervukhin, V. V.; Rasulev, U. K. Separation of Ions According to Mobility in Strong AC Fields. Sov. Tech. Phys. Lett. 1991, 17, 446-447.

20. (a) Purves, R. W.; Barnett, D. A.; Guevremont, R. Separation of Protein Conformers Using Electrospray-High Field Asymmetric Waveform Ion Mobility Spectrometry-Mass Spectrometry. Int. J. Mass Spectrom. 2000, 197, 163-177. (b) Purves, R. W.; Barnett, D. A.; Ells, B.; Guevremont, R. Elongated Conformers of the charge states +11 to +15 of Bovine Ubiquitin Studied using ESI-FAIMS-MS. J. Am. Soc. Mass Spectrom. 2001, 12, 894-901. (c) Purves, R. W.; Barnett, D. A.; Ells, B.; Guevremont, R. Gas-Phase Conformations of the $[\mathrm{M}+2 \mathrm{H}]++$ Ion of Bradykinin Investigated by Combining High-Field Asymmetric Waveform Ion Mobility Spectrometry, Hydrogen/Deuterium Exchange, and Energy-Loss Measurements. Rapid Commun. Mass Spectrom. 2001, 15, 1453-1456. (d) Borysik, A. J. H.; Read, P.; Little, D. R.; Bateman, R. H.; Radford, S. E.; Ashcroft, A. E. Separation of $\beta 2$-Microglobulin Conformers by HighField Asymmetric Waveform Ion Mobility Spectrometry (FAIMS) Coupled to Electrospray Ionization Mass Spectrometry. Rapid Commun. Mass Spectrom. 2004, 18, 2229-2234.

21. (a) Purves, R. W.; Guevremont, R.; Day, S.; Pipich, C. W.; Matyjaszczyk, M. S. Mass Spectrometric Characterization of a High-Field Asymmetric Waveform Ion Mobility Spectrometer. Rev. Sci. Instrum. 1998, 69, 4094-4105. (b) Guevremont, R.; Purves, R. W. Atmospheric Pressure Ion Focusing in a HighField Asymmetric Waveform Ion Mobility Spectrometer. Rev. Sci. Instrum. 1999, 70, 1370-1384. (c) Krylov, E. V. A Method of Reducing Diffusion Losses in a Drift Spectrometer. Tech. Phys. 1999, 44, 113-116. (d) Guevremont, R.; Purves, R. W.; Barnett, D. A.; Ding, L. Ion Trapping at Atmospheric Pressure (760 Torr) and Room Temperature with a High-Field Asymmetric Waveform Ion Mobility Spectrometry/Mass Spectrometry. Int. J. Mass Spectrom. 1999, 193, 45-56. 
22. Jurchen, J. C.; Williams, E. R. Origin of Asymmetric Charge Partitioning in the Dissociation of Gas-Phase Protein Homodimers. J. Am. Chem. Soc. 2003, 125, 2817-2826.

23. (a) Beu, S. C.; Laude, D. A. Open Trapped Ion Cell Geometries for Fourier-Transform Ion Cyclotron Resonance Mass Spectrometry. Int. J. Mass Spectrom. Ion Processes 1992, 112, 215-230. (b) Guan, S. H.; Marshall A. G. Ion Traps for FourierTransform Ion-Cyclotron Resonance Mass SpectrometryPrinciples and Design of Geometric and Electronic Configurations. Int. J. Mass Spectrom. Ion Processes 1995, 146, 241-296. (c) Vartanian, V. H.; Laude, D. A. Optimization of a FixedVolume Open Geometry Trapped Ion Cell for Fourier Transform Ion Cyclotron Mass Spectrometry. Int. J. Mass Spectrom. Ion Processes 1995, 141, 189-200. (d) Easterling, M. L.; Mize, T. H.; Amster, I. J. MALDI FTMS Analysis of Polymers: Improved Performance Using an Open Ended Cylindrical Analyzer Cell. Int. J. Mass Spectrom. 1997, 169, 387-400. (e) Kuhnen, F.; Spiess, I.; Wanczek, K. P. Theoretical Comparison of Closed and Open ICR Cells. Int. J. Mass Spectrom. 1997, 167, 761-769.

24. (a) Beu, S. C.; Laude, D. A. Elimination of Axial Ejection During Excitation with a Capacitively Coupled Open Trapped-Ion Cell for Fourier-Transform Ion Cyclotron Resonance Mass Spectrometry. Anal. Chem. 1992, 64, 177-180. (b) O'Conner, P. B.; McLafferty, F. W. High-Resolution Ion Isolation with the Ion Cyclotron Resonance Capacitively Coupled Open Cell. J. Am. Soc. Mass Spectrom. 1995, 6, 533-535.

25. R Development Core Team (2004). R: A Language and Environment for Statistical Computing. $R$ Foundation for Statistical Computing; 2004, version 2.0.1, Vienna, Austria.

26. (a) Barnett, D. A.; Ells, B; Guevremont, R.; Purves, R. W.; Viehland, L. A. Evaluation of Carrier Gases for use in High-
Field Asymmetric Waveform Ion Mobility Spectrometry. J. Am. Soc. Mass Spectrom. 2000, 11, 1125-1133. (b) Spangler, G. E.; Raanan, A. M. Application of Mobility Theory to the Interpretation of Data Generated by Linear and RF Excited Ion Mobility Spectrometers. Int. J. Mass Spectrom. 2002, 214, 95-104.

27. (a) Gard, E.; Willard, D.; Bregar, J.; Green, M. K.; Lebrilla, C. B. Site-Specificity in the H/D Exchange Reactions of Gas-Phase Protonated Amino-Acids with CH3OD. Org. Mass Spectrom. 1993, 28, 1632-1639. (b) Gard, E.; Green, M. K.; Bregar, J.; Lebrilla, C. B. Gas-Phase Hydrogen/Deuterium Exchange as a Molecular Probe for the Interaction of Methanol and Protonated Peptides. J. Am. Soc. Mass Spectrom. 1994, 5, 623-631. (c) Green, M. K.; Lebrilla, C. B. The Role of Proton-Bridged Intermediates in Promoting Hydrogen/Deuterium Exchange in Gas-Phase Protonated Diamines, Peptides, and Proteins. Int. J. Mass Spectrom. 1998, 175, 15-26.

28. (a) Campbell, S.; Rodgers, M. T.; Marzluff, E. M.; Beauchamp, J. L. Structural and Energetic Constraints on Gas-Phase Hydrogen/Deuterium Exchange Reactions of Protonated Peptides with D2O, CD3OD, CD3CO2D, and ND3. J. Am. Chem. Soc. 1994, 116, 9765-9766. (b) Campbell, S.; Rodgers, M. T.; Marzluff, E. M.; Beauchamp, J. L. Deuterium Exchange Reactions as a Probe of Biomolecule Structure. Fundamental Studies of Gas Phase H/D Exchange Reactions of Protonated Glycine Oligomers with D2O, CD3OD, CD3CO2D, and ND3. J. Am. Chem. Soc. 1995, 117, 12840-12854. (c) Lee, S. W.; Lee, H. N.; Kim, H. S.; Beauchamp, J. L. Selective Binding of Crown Ethers to Protonated Peptides Can Be Used to Probe Mechanisms of H/D Exchange and Collision-Induced Dissociation Reactions in the Gas Phase. J. Am. Chem. Soc. 1998, 120, $5800-5805$. 